\title{
The revelation from Life-Cycle Environmental Management System of Foreign military equipment
}

\author{
Zhongmin Liu*, Zhuo Yang, Zelong Zhou, Shanchao Tu \\ Wuhan Mechanical College, Wuhan, 430075, China \\ * Corresponding author. E-mail: 1137645276@qq.com
}

\begin{abstract}
This paper analyzes life-cycle environmental management of the foreign military weapons and equipment in development, production, use, decommissioning. Draw lessons from the practice and experience in weapons and equipment. Environmental protection concept should be implemented research in the whole life cycle management, and environmental protection equipment should be developed. Countermeasures and Suggestions in environmental protection are proposed.
\end{abstract}

Key words: Military weapons and equipment, Environmental management

\section{INTRODUCTION}

Foreign military weapons and equipment construction based on life-cycle management theory and the sustainable base construction is of green development trend, embodied in the following three aspects.

(1)Weapons and equipment research and manufacture are developing in green trend.

Weapons and equipment of green refers to minimizing the threat to environment and human with green technology, during manufacturing, use and destruction of the weapon equipment, on the premise of meet the military performance. Green means less pollution, less risk, resources, energy saving, etc. The United States, Britain and other countries set guidelines and rules in accordance with the requirements of "green weapons", at the same time in the 1990s develop the green weapon and equipment.

In 1995 the United States department of defense environmental security certification organization and strategic environment research development organization jointly develop "green bullet", aimed at reducing volatile substances, ozone-depleting substances and heavy metals in the process of manufacturing, use and final disposal of caliber weapons. Sustainable development and environmental manual of the British ministry of defence requires that "green design" is used in the research and development of any modern weapons, minimizing its environmental impact. BAE develops a new generation of energy saving and recycling of explosives, whose explosive waste and scrap ammunition can be used as crop fertilizer.

(2) Environmental protection in weapon test and train

Energy and chemicals release into the soil, air and water during, eventually cause air, water, soil and ecological environment pollution and destruction.

The US army takes environmental protection action to improve the training living and working environment of soldier, environment, and to reduce negative effects on the environment with weapons and equipment including weapons and equipment, use process and retirement, which mainly show as follows.

A sound environmental establishment system. Set the environmental protection agency from the Ministry of National Defense to all the services and arms. A complete environmental protection laws and regulations system. America's environmental protection laws and regulations system is perfect, distinct, of strong operability, strictly in accordance with the implementation and strict supervision and management. The sustainable development goals. American troops establish the target of sustainable development of water environment, and formulate the corresponding technical measures. The advanced research system. Many of the test agency undertake national major projects on environment, and has the international advanced level in this field. The perfect environmental education and training system. American environmental education and training is not only confined to the environmental protection professionals, more is facing all the troops. Strengthen the management of environmental pollution and recovery. American troops in the aspect of 
environmental pollution and recovery mainly adopts three ways: the natural recovery, technical repair, the construction of natural wetlands.

(3) Weapons and equipment maintenance and retired development "3R" theory

American troops have realized "deep sea dumping" and "deep landfill" cannot solve the pollution of the environment caused by the weapons and equipment scrapped, but deepen and spread environmental pollution degree and range of the waste. Dod in view of the concept of sustainable development proposed reuse, reduce)and recycle theory, based on the theory of the full life cycle. From equipment research and development stage, promote the use of green energy-saving materials and technology. From the source control equipment scrap pollution and harm to the environment. The retired weapons will be part of the mod surplus assets for unified handling. DRMS (the defense reutilization and marketing service) is established on a global scale in the United States as the main military base guarantee support, realizing reusing the defence materiel. Disposal equipment maintenance and regeneration of aeronautics and astronautics center is established for military retired equipment. American troops often renovate and modificate retired aircraft and then sale them on the international arms market. Implementing equipment remanu- -facturing is U.S. military equipment support and huge Arsenal maintain strategic measures and important means of operation.

\section{REVELATION FROM FOREIGN ENVIRONMENT PROTECTION AND MANAGEMENT OF MILITARY EQUIPMENT}

Reference especially the foreign experience in weapons and equipment of environmental protection. Combine with the present situation and development trend and the equipment construction. Complete organization and management, environmental protection system, laws and regulations and environmental technology research and development and other aspects. Implement equipment life-cycle management concept in equipment research and development, equipment order acceptance, equipment, test with test, the equipment use and disposal equipment retired five stages is the heaviest.

(1) The implementation of the concept of environmental protection

Weapons and equipment research and development and equipment order stage is the source of the energy consumption and environmental pollution which effect the equipment system. Environmental protection concept is under environmental targets of sustainable development theory. Environ- -mental protection, reducing pollution, reducing consumption of energy resources is the environmental protection goal of common people all over the world. The concept that Equipment is more important than environmental protection, cause military environmental pollution worse and worse. The environmental protection problem has been promoted to the same height. Equipment development, development of fighting capacity, enhance at the same time must pay attention to and solve environmental problems produced directly and indirectly. In this respect there is a lot to draw lessons from foreign experiences and lessons. To carry out environmental protection concept could reduce the environmenta impact of whole life cycle from equipment.

From the respect such as the purpose, the characteristics of equipment, the use of law, scrap disposal, demonstrate and analysis environmental problems produced in equipment manufacturing, use and scrap on whole life cycle. Set the environmental protection target. Include environmental targets in military technology target, at the same time, take the environmental protection goal as a required element of the independent or key indicators into the equipment research and development, order, design, manufacture, inspection, use and scrap disposal process.

Around the whole life cycle of building equipment achieve environmental objectives. Set environmental standard system and standard, perfect preparation and post setting. Establish and perfect the system of environmental protection work. Make the environmental impact assessment, environmental monitoring, environmental supervision, environmental pollution and so on each work into effect.

(2) Development of Green weapons

Green weapons named environmental protection weapons, is proposed according to high destruction and destructive weapons and does not produce or produce less pollution to the natural environment. environmentally friendly and does not destroy the ecological balance of the weapons. Actually both consider weapons of destruction and the green consequences of weapons is a kind of typical antinomy relationship. The reaction is benefit and the clash of civilizations. But look from the international development trend of weapon equipment, high technology and high strength war require weapons and equipment to develop in the direction of green. Green weapon equipment development improve our weapons and equipment, which control and reduce the rate of volatile substances, ozone-depleting substances, and lead the release of harmful substances and spread, which is the army for the duty of public environmental protection career.

Our existing heavy equipment in diesel and gasoline as fuel, make noise and exhaust gas, which cannot meet the control standards of the state and have big impact on the environment. The poor driving conditions, especially the tracked armored equipment, for the driver and occupants caused harm to body health, which objectively also affected the military exercises, training level. Armored forces use lead and zinc battery. The charging 
chamber releasing of acid mist basic without any protection and disposal measures, not only pollute on the surrounding environment and hazard management personnel's physical health. Weapons and equipment are highly polluting and energy-consuming equipment。The existing clean energy is low efficiency and high cost constraints. So development of efficient and clean alternative fuels, such as hydrogen, solar energy, can effectively reduce the exhaust emissions of harmful substances, reduce the amount of pollution on the surrounding atmosphere and the dangers of operating space environment.

Material is the basis for the weapons and equipment, which not only effect weapon equipment performance and energy consumption, but also effect dismantling and recycling. New weapons and equipment materials research is key technology in the development of today's world competition in the military field. From the main body of the structural materials of equipment to the equipment functional composite materials, materials determines the degree of equipment and the application of high technology.

(3) The measures against pollution

To prevent and control environmental pollution in use process with equipment is the chief problem of the current equipment of environmental protection. The reason is that the existing equipment environmental pollution already exists, and the surrounding environment pollution and the user's damage has occurred. The camp pollution should be centralized treat, improving the efficiency of treatment. Engineers are the main force on pollution control. And special management and technical personnel are in need.

Equipment cannot be incentralized treatment, especially in the shooting range, in the proving ground training and exercises. The pollution generated by the weapons will improve the soil heavy metal content such as lead, and pollute the groundwater, result in ecological function degradation of ecological environment in the biodiversity loss. The implementation of ecological restoration on a regular basis. can deal with the problem.
Ecological restoration need experts, engineers and even landscape engineer to participate in.

Green disposal is the effective ways for retired equipment to environmental protection, equipment remanufacturing and save resources. Equipment recycling, remanu- -facturing and equipment disposal equipment technology research should be carried out. special retirement equipment disposal base, perfect system and management system should be established.

\section{CONCLUSIONS}

With the rapid development of science and technology, the role of equipment in military construction and war is more and more important, which is the decisive role, whether it's wartime role play or cold war threat. Weapons and equipment capacity is the main index in the evaluation forces military capabilities. The development of the weapon equipment construction is the main development direction of the army. Reduce environmental pollution need environmental protection concepts carried out. The organization and management, technology research, development and governance repair work in equipment research and development, manufacture, test, test, drills, storage, maintenance, security, retirement, and the regeneration process should be done. Equipment manufacturing research and development relates to the overall situation of national defense and army building, which has a long way to go.

\section{Acknowledgement}

This project is supported by Teaching Reform Funding of Wuhan Mechanical Technology College.

\section{References}

[1] Ye Gang. Environmental problems have generated a new model of military technology development [M]. These automation, 2011.30 (8) : 40-42.

[2] Xin Tao etc. The retired scrap disposal equipment research and enlightenment[J]. Resources science, 2010.32 (12) : 2286-2291.

[3] Jiang Zhongzhi, Cao Juhui etc. U.S. military weapons and equipment construction of environmental protection [M]. Academic, 2009 (2) . 